ISSN 1392-3196 / e-ISSN 2335-8947

Zemdirbyste-Agriculture, vol. 103, No. 1 (2016), p. 3-10

DOI 10.13080/z-a.2016.103.001

\title{
The effect of alternative cropping systems on the changes of the main nutritional elements in the soil
}

\author{
Laura MASILIONYTE், Stanislava MAIKŠTĖNIENE் \\ Joniškèlis Experimental Station, Lithuanian Research Centre for Agriculture and Forestry \\ Joniškèlis, Pasvalys distr., Lithuania \\ E-mail: laura.masilionyte@gmail.com
}

\begin{abstract}
Experiments were conducted at Joniškèlis Experimental Station of the Lithuanian Research Centre for Agriculture and Forestry in 2006-2013, on an Endocalcari-Endohypogleyic Cambisol (CMg- $n$-w-can), which is characterised by low phosphorus and high potassium contents with low $(<2.0)$ and moderate $(>2.1)$ humus content. The research was carried out in the crop rotation's grass-cereal sequence: perennial grasses (grown as green manure) $\rightarrow$ winter wheat. The aim of experiments is to determine the changes of biogenic soil elements in the organic cropping systems by using farmyard manure and aftermath of red clover for green manure or their combinations for winter wheat fertilization, and in sustainable cropping systems - by replenishing the amount of nutritional elements with mineral fertilizers. The NPK balance was negative in the organic cropping system in the soil with both low and moderate levels of soil humus when only green manure had been used as fertilizer for winter wheat. The NP balance was strongly positive and $\mathrm{K}$ was significantly in excess in the organic cropping system when the green manure had been used in combination with $40 \mathrm{Mg} \mathrm{ha}^{-1}$ of farmyard manure. A marked reduction in the available phosphorus content in the soil with different humus levels was established when green manure or $40 \mathrm{Mg} \mathrm{ha}^{-1}$ of farmyard manure or their combinations had been applied. Also, potassium levels increased in the organic cropping system where green or farmyard manure had been applied. When $40 \mathrm{Mg} \mathrm{ha}^{-1}$ of farmyard manure and $\mathrm{N}_{30}$ mineral fertilizer had been used in the sustainable cropping system to promote straw mineralization, the nitrogen balance in the soil with the low humus content was slightly positive, but in the soil with moderate humus content it was strongly negative; in the soil of both humus levels phosphorus balance was slightly positive and potassium balance was significantly excessive. In the both soils with low and moderate humus content, in the sustainable cropping systems that had used the perennial grass aftermath as green manure with minimum rates of mineral fertilizer $\mathrm{N}_{30} \mathrm{P}_{60} \mathrm{~K}_{60}, \mathrm{~N}$ balance was negative, $\mathrm{P}$ - marginally positive. In the soil with low humus content $\mathrm{K}$ value was positive, in the soil with moderate humus content - marginally negative. In the sustainable cropping system, where perennial grass aftermath for green manure and $\mathrm{N}_{30} \mathrm{P}_{60} \mathrm{~K}_{60}$ had been used for winter wheat during two 4-field crop rotations the available phosphorus and potassium quantity in the soil low and moderate in humus status showed a trend towards decreasing.
\end{abstract}

Key words: green and farmyard manure, mobile $\mathrm{P}_{2} \mathrm{O}_{5}$ and $\mathrm{K}_{2} \mathrm{O}$, nutrient balance, organic and sustainable cropping systems.

\section{Introduction}

Soil fertility is mainly determined by the amount of organic matter present and their humification levels, which in turn, determine the majority of the soil's physical and agrochemical properties. The degradation and synthesis of organic materials in the soil always take place and therefore, the balance of the degradation and synthesis of organic materials occur in natural ecosystems. The direction of these processes can be damaged in the agrocenoses influenced by different anthropogenic factors (Cardelli et al., 2012; Franzluebbers, 2012). Up to a certain time, plant nutrition and agrosystem productivity improve if the plants are abundantly fertilized with a mineral fertilizer. However, when the nitrogen content in the soil is high, bacteria start to decompose the humus itself, starting humus degradation, which results in the incorporated fertilizer failing to ensure an adequate extra yield (Feller et al., 2012).

Successful cultivation of perennial grasses allows for the reduction of the negative impact of anthropogenic activities and the retention of organic material balance in the soil. Perennial grasses induce the run of the processes of organic material transformation in terms of humification, which determines the accumulation of humus materials (Gliessman, 2015). The application of environmentally sustainable cropping systems and different organic fertilizer results in retaining potential soil fertility; however, they are problematic in ensuring the optimum plant nutrition (Standing, Killham, 2011; Tiziano et al., 2011).

The nutrients present in organic fertilizer result in lower extra yield, in terms of cultivated plants, after incorporation due to a lower utilisation rate compared to the same amount present in mineral fertilizer. However, their action is longer (Diacono, Montemurro, 2010; 
Ladha et al., 2011). Plants assimilate only a certain portion of the phosphorus and potassium amounts incorporated with organic fertilizer, and therefore, only a certain portion of nutrients available for the assimilation by the following year's plants remains in the soil (Osman, 2013). Therefore, the productivity of a crop rotation depends both on the amount of the fertilizer incorporated and on its distribution within the crop rotation (Oerke et al., 2012). While using only mineral fertilizer, the intensity of plant nutrition takes place in a pulsing manner as nitrogen leaches out especially rapidly and plants feel stress during certain stages (Cerný et al., 2012). To compensate for the resources of nutrients taken out with plants during harvesting in intensive and integrated agricultural systems, organic and mineral fertilizers, as well as their combinations, are applied to ensure a stable supply of the main nutrients to plants during their entire developmental period (Benton Jones, 2012; Roychowdhury et al., 2013).

When it is not possible to apply mineral fertilizer in the systems of alternative agriculture, one of more valuable organic fertilizers maintaining soil fertility is solid manure. The literature indicates that its composition is abundant with the materials required by plants and a substantial part of the organic materials present in manure are already humified to some extent. Systematic fertilization with manure increases the sorption ability of soil (Clough et al., 2013). In addition, different macroand microelements, physiologically active materials and microorganisms are incorporated into soil together with the organic material (Eleiwa et al., 2012). Therefore, manure is important to nearly all agrochemical, physical and microbiological properties of soil, as well as the regimes of moisture and air (Edesi et al., 2012). The humic substances present in organic fertilizer are characterised by high buffer capacity and sorption receptivity, which help to reduce soil acidity and the concentration of salts in it, as well as protect the soil against unfavourable factors. Manure has all of the primary elements of plant nutrition. However, their percentages and amounts vary to satisfy all of the needs of plants (Edesi et al., 2012; Kumar et al., 2013).

During the first year following the incorporation of organic materials, the available main nutritional elements are not sufficient for plants, and therefore, other fertilizers must compensate for them. When only organic fertilizers are applied in organic agrosystems, phosphorus becomes a yield-limiting factor in the soils of different richness (Fageria et al., 2011; Tan et al., 2013). Therefore, the majority of authors suggest using the biomass of perennial grasses aftermath or annual plants cultivated as catch crops for green manure in organic agrosystems. Some investigations indicate that perennial grasses and their biomass used for green manure possess more universal benefits due to their well-developed root system compared to the annual plants cultivated as catch crops (Arlauskiene et al., 2011; Janušauskaitė et al., 2013).

In organic agrosystems, in spite of the fact that the Fabaceae family plants can supply themselves with nitrogen from the atmosphere, phosphorus or potassium can become the limiting factor for their yield (Sedlár et al., 2011; Cerný et al., 2012). Some authors indicate that phosphorus is especially necessary for emerging fabaceous plants, as it directly stimulates the development and mobility of rhizobium bacteria (de-Bashan et al., 2012; Khan et al., 2013). There are data in the literature indicating that in fixing symbiotic nitrogen, potassium has even higher importance compared to phosphorus. However, potassium fertilizer can be less effective as it is usually present in higher amounts in soil (Chapin et al., 2012). However, investigations indicate great activity levels of perennial grass symbiosis, especially that of red clover, without applying any mineral fertilizers (Spiess, 2011). Perennial grasses, as well as their roots, residues and biomass, incorporated as green manure, can optimise the ratio of biogenic elements incorporated in the soil (Masilionyte, Maikštėnienè, 2010; Luce et al., 2011).

In order to maintain soil fertility under manure shortage conditions in organic cropping systems perennial grass biomass is applied as green manure. The objective of the study was to determine the changes in the biogenic elements in the soil of the organic cropping systems where farmyard manure, red clover aftermath for green manure or combinations of both had been used for winter wheat fertilization and in the soil of the sustainable cropping systems where winter wheat had received organic fertilization supplemented with mineral fertilizers.

\section{Materials and methods}

The experiments were conducted at the Joniškèlis Experimental Station of the Lithuanian Research Centre for Agriculture and Forestry in the first 4-course rotation 2006-2009 and in the second rotation 2010-2013. The soil of the experimental site is an EndocalcariEndohypogleyic Cambisol (CMg-n-w-can) according to FAO. The objective of the study was to determine the changes in the biogenic elements in the soil of the organic cropping systems where farmyard manure, red clover aftermath for green manure or combinations of both had been used for winter wheat fertilization and in the soil of the sustainable cropping systems where winter wheat had received organic fertilization supplemented with mineral fertilizers.

The experiments were carried out in the soil of two soil humus content levels - factor A: low humus content (1.90-2.01\%) and moderate humus content (2.10 $2.40 \%)$. Cropping systems were investigated under both soil humus content levels - factor B: organic I - aftermath perennial grasses as green manure, organic II - farmyard manure $40 \mathrm{Mg} \mathrm{ha}^{-1}+$ aftermath perennial grasses as green manure, sustainable I - farmyard manure $40 \mathrm{Mg} \mathrm{ha}^{-1}$ and sustainable II - aftermath perennial grasses as green manure $+\mathrm{N}_{30} \mathrm{P}_{60} \mathrm{~K}_{60}$.

The soil agrochemical properties at a depth of 0-20 cm before the establishment of the experiments varied as follows: $\mathrm{pH}_{\mathrm{KCl}}-6.0-6.1$, the humus amount established in low humus content soil was $1.90-2.00 \%$, in moderate humus content soil $-2.10-2.40 \%$; the amount of mobile phosphorus $\left(\mathrm{P}_{2} \mathrm{O}_{5}\right)$ in low humus content soil was $67-125 \mathrm{mg} \mathrm{kg}^{-1}$, in moderate humus content soil - $115-145 \mathrm{mg} \mathrm{kg}^{-1}$; the amount of mobile potassium $\left(\mathrm{K}_{2} \mathrm{O}\right)$ in low humus content soil was $185-230 \mathrm{mg} \mathrm{kg}^{-1}$, in moderate humus content soil $-220-230 \mathrm{mg} \mathrm{kg}^{-1}$. The soil bulk density in topsoil was $1.42-1.48 \mathrm{Mg} \mathrm{m}^{-3}$, total porosity $-43.1-45.1 \%$.

Crop rotation: spring barley (Hordeum vulgare L.) variety 'Ula' + undersown $\rightarrow$ perennial grasses (red clover (Trifolium pratense L.) variety 'Vyliai') $\rightarrow$ winter wheat (Triticum aestivum L.) variety 'Ada' $\rightarrow$ field pea (Pisum sativum L.) variety 'Pinochio'. The research was 
carried out in the crop rotation's grass-cereal sequence: perennial grasses (aftermath as green manure) $\rightarrow$ winter wheat.

The experiments were set up in a 4-course crop rotation spread over time and space. Each replication was composed of two different humus content levels (factor A), and in each of them, green manure and farmyard manure or their combinations were used (factor B). A randomised plot design was used with the main plot size of $21 \times 5 \mathrm{~m}=105 \mathrm{~m}^{2}$ and the harvested plot size of $14 \times$ $2.3 \mathrm{~m}=32.2 \mathrm{~m}^{2}$.

After the plants had germinated, each plot was marked with four $0.25 \mathrm{~m}^{2}$ microplots, from which the accumulated overground biomass was determined by a weighing method. Before incorporating the overground biomass into the soil, the amount of dry matter (DM), and the concentrations $(\%)$ of nitrogen $(\mathrm{N})$, phosphorus $(\mathrm{P})$ and potassium $(\mathrm{K})$ were determined. Nitrogen was determined by Kjeldahl (ISO 20483:2006), phosphorus by colorimetric, and potassium by flame photometric methods. The amount of nutrients accumulated in the biomass was recalculated in $\mathrm{kg} \mathrm{ha}^{-1}$.

The NPK nutrient balance was calculated by finding the difference between: the contents of the main biogenic elements (the oxides present in mineral fertilizer were converted into pure elements) incorporated into the soil together with organic and mineral fertilizer and the

Table 1. Weather conditions in 2006-2013

\begin{tabular}{|c|c|c|c|c|c|c|c|c|c|}
\hline \multirow{2}{*}{ Month } & \multicolumn{8}{|c|}{ Year } & \multirow{2}{*}{ Long-term average } \\
\hline & 2006 & 2007 & 2008 & 2009 & 2010 & 2011 & 2012 & 2013 & \\
\hline \multicolumn{10}{|c|}{ Air temperature ${ }^{\circ} \mathrm{C}$} \\
\hline April & 6.7 & 6.2 & 7.3 & 8.4 & 6.8 & 8.5 & 7.1 & 4.6 & 6.2 \\
\hline May & 12.2 & 13.5 & 10.8 & 12.9 & 13.6 & 14.1 & 12.5 & 16.2 & 12.3 \\
\hline June & 16.3 & 17.1 & 14.8 & 14.4 & 15.6 & 17.7 & 15.1 & 18.6 & 15.6 \\
\hline July & 20.9 & 17.4 & 17.3 & 18.1 & 22.1 & 19.0 & 19.9 & 18.9 & 17.2 \\
\hline August & 18.6 & 19.2 & 17.4 & 16.2 & 19.8 & 17.3 & 16.4 & 18.5 & 17.1 \\
\hline September & 14.9 & 12.7 & 11.4 & 13.7 & 11.6 & 13.9 & 13.9 & 12.4 & 12.0 \\
\hline October & 9.4 & 7.3 & 8.1 & 4.7 & 5.1 & 13.9 & 7.4 & 8.4 & 6.3 \\
\hline \multicolumn{10}{|c|}{ Precipitation $\mathrm{mm}$} \\
\hline April & 23.3 & 12.8 & 54.6 & 18.2 & 23.2 & 16.1 & 73.0 & 36.9 & 37.4 \\
\hline May & 32.5 & 49.0 & 12.9 & 17.2 & 69.3 & 38.4 & 53.1 & 73.4 & 45.6 \\
\hline June & 6.3 & 67.7 & 36.2 & 80.9 & 54.4 & 53.2 & 57.6 & 44.4 & 59.4 \\
\hline July & 28.5 & 107.0 & 66.1 & 107.6 & 74.4 & 95.6 & 96.2 & 53.0 & 69.2 \\
\hline August & 139.8 & 56.8 & 116.5 & 49.8 & 57.6 & 69.9 & 66.6 & 38.8 & 67.9 \\
\hline September & 48.2 & 51.7 & 6.5 & 37.4 & 28.0 & 40.0 & 22.5 & 81.1 & 57.9 \\
\hline October & 68.8 & 53.2 & 74.8 & 72.6 & 22.6 & 18.7 & 62.1 & 14.8 & 45.5 \\
\hline
\end{tabular}

In 2006, the vegetation period was dry: in April, the precipitation accounted for $62.3 \%$, in May $-71.3 \%$, in June $-11.4 \%$ and in July $-4.12 \%$ of the multi-annual precipitation rate. The average air temperature was close to the long-term average. However, the yield of the main crops was low due to the drought. During the vegetation period, the months of August-October were characterised by excessive moisture and the amount of precipitation exceeded the long-term average by $85.5 \mathrm{~mm}$. Therefore, it was the most favourable for plants growth and development compared to all other vegetation periods.

2007. The perennial grass vegetation resumed in the middle of April. It was comparatively warm during the vegetation period of the main crops (May-July). The data corresponded to the long-term averages and the amount of precipitation was slightly higher compared to the long-term averages.

2008. The average daily air temperature of the main crop vegetation period (May-August) differed contents lost with the main production of plants. The NPK balance is calculated by using the following formula:

$$
\begin{aligned}
& \text { NPK } \text { balance }=\mathrm{NPK}_{\text {incorporated into soil together with organic and }}-\mathrm{NPK}_{\text {lost with the main production }}{ }^{\text {mineral fertilizer }}
\end{aligned}
$$

The content of nutrients accumulated in the biomass of the secondary production - winter wheat straw, field pea - was not included into the balance as it returned into the soil. Other authors indicate such calculation of balance (Tripolskaja, 2005).

Statistical analysis. The experimental data of plant productivity and chemical composition indicators were processed by a two-factor analysis of variance and correlation-regression methods using a software package SELEKCIJA. The symbols * and ** denote statistically significant results at $95 \%$ and $99 \%$ probability level, respectively (Tarakanovas, Raudonius, 2003).

Meteorological conditions. The meteorological conditions are presented and assessed on the basis of the data from the meteorological site of Joniškèlis Experimental Station. The meteorological conditions during the experimental period were contrasting. During the plant vegetation period, they varied dramatically in terms of precipitation amount and temperature regime (Table 1). scarcely compared to the long-term average. The plants lacked moisture; in May, the precipitation was $32.7 \mathrm{~mm}$ lower than the long-term average. In August, the precipitation was higher by $48.6 \mathrm{~mm}$ compared to the long-term average and that ensured the appropriate development of perennial grasses.

2009. Dry April and May slowed down the development of perennial grasses. The average daily temperature was $2.2^{\circ} \mathrm{C}$ and $0.6^{\circ} \mathrm{C}$, respectively, which is higher than the long-term average and the amount of precipitation during these two months, was $47.6 \mathrm{~mm}$ lower compared to the long-term average. However, June and July were very wet and the amount of precipitation was 80.9 and $107.6 \mathrm{~mm}$, respectively. September was very dry with the amount of precipitation being $35.4 \%$ lower and the daily average temperature of the month being $1.7^{\circ} \mathrm{C}$ higher compared to the long-term average.

2010. The precipitation in April amounted to $61.2 \%$ of the multi-annual rate of precipitation and 
the average air temperature was close to the long-term average. In May, the precipitation was 34.2\% higher and it was slightly warmer compared to the long-term averages. June and July were close to the long-term averages, both in terms of precipitation and temperature.

2011. In April-July, the temperature was slightly higher than usual. At the beginning of plant vegetation, the precipitation was twice as low as compared to the long-term averages. June was close to the long-term average and in July, the precipitation amount was $72.4 \%$ higher than usual.

2012. In 2012, July was marginally warmer and the amount of precipitation was somewhat higher compared to the long-term average. September and October were somewhat warmer than usual and the amount of precipitation in September was 2.6 times higher and in October $26.7 \%$ lower compared to the long-term average.

2013. April was $25.8 \%$ colder than usual and the amount of precipitation corresponded to the long-term rates. During all vegetation periods from May to August, the air temperature was higher than usual. However, the precipitation in June-August was 23.4-42.6\% lower than usual.

\section{Results and discussion}

After the first 4-course rotation the data analysis showed that having applied green manure and $40 \mathrm{Mg}$ $\mathrm{ha}^{-1}$ of farmyard manure for winter wheat fertilization in the organic cropping systems the yield did not increase significantly; the NP balance was positive and the content of K was highly excessive. Having applied $40 \mathrm{Mg} \mathrm{ha}^{-1}$ of farmyard manure for winter wheat fertilization and $\mathrm{N}_{30}$ in ammonium nitrate form for its straw mineralization in the sustainable cropping system, the NPK balance was positive in the soil of low humus content and the nitrogen balance was negative in the soil of moderate humus content due to more active plant growing conditions and a higher nitrogen removal together with the wheat yield. The application of integrated fertilization system while incorporating perennial grass aftermath and using mineral fertilizer in sustainable cropping results in the highest yield of cereals and the highest content of biogenic elements for both humus levels; the nitrogen balance was negative due to readily available nutrients from the mineral fertilizer while PK remained marginally positive (Masilionyte, Maikštenienè, 2010).

In the majority of cases of the continued research of crop rotation II a similar trend of NPK balance variation was determined for crop rotation I. The average NPK balance data of the second rotation in 2010-2013 are presented in Table 2.

The balance between nitrogen introduced into the soil with organic and mineral fertilizers and that removed with the yield varied markedly between the different cropping systems. In the organic I cropping system, in both humus status levels, when using only aftermath of perennial grasses biomass, for fertilization, irrespective of the fact that removal with winter wheat yield was low, $\mathrm{N}$ balance was negative.

Table 2. Balance of nutrients in crop rotation II

\begin{tabular}{|c|c|c|c|c|}
\hline \multirow{2}{*}{$\begin{array}{l}\text { Cropping system } \\
\text { (factor B) }\end{array}$} & \multirow{2}{*}{ Organic and mineral fertilizers } & \multicolumn{2}{|c|}{$\begin{array}{l}\text { Soil humus status } \\
\text { (factor A) }\end{array}$} & \multirow{2}{*}{$\begin{array}{c}\text { Mean } \\
\text { (factor B }\end{array}$} \\
\hline & & low & moderate & \\
\hline \multicolumn{5}{|c|}{$\mathrm{N} \mathrm{kg} \mathrm{ha}^{-1}$} \\
\hline Organic I & aftermath of perennial grass & -86.02 & -91.53 & -88.77 \\
\hline Organic II & aftermath of perennial grass + farmyard manure $40 \mathrm{Mg} \mathrm{ha}^{-1}$ & $146.94 *$ & $68.30 *$ & $107.62 * *$ \\
\hline Sustainable I & farmyard manure $40 \mathrm{Mg} \mathrm{ha}^{-1}$ & 3.81 & -31.02 & $-13.60 *$ \\
\hline \multirow[t]{3}{*}{ Sustainable II } & aftermath of perennial grass $+\mathrm{N}_{30} \mathrm{P}_{60} \mathrm{~K}_{60}$ & -120.61 & -123.99 & -122.30 \\
\hline & Mean (factor A) & -13.97 & $-44.56 *$ & -29.26 \\
\hline & $\mathrm{LSD}_{05}: \mathrm{A}-19.861, \mathrm{~B}-34.585, \mathrm{~A} \times \mathrm{B}$ & 0.812 & & \\
\hline \multicolumn{5}{|c|}{$\mathrm{LSD}_{05} \cdot \mathrm{A}-19.001, \mathrm{D}-54.505, \mathrm{~A} \times \mathrm{D}-50.812$} \\
\hline Organic I & aftermath of perennial grass & -23.42 & -26.10 & -24.76 \\
\hline Organic II & aftermath of perennial grass + farmyard manure $40 \mathrm{Mg} \mathrm{ha}^{-1}$ & $27.93 *$ & $25.71 *$ & $26.82 *$ \\
\hline Sustainable I & farmyard manure $40 \mathrm{Mg} \mathrm{ha}^{-1}$ & 20.83 & 14.74 & 17.78 \\
\hline \multirow[t]{2}{*}{ Sustainable II } & aftermath of perennial grass $+\mathrm{N}_{30} \mathrm{P}_{60} \mathrm{~K}_{60}$ & $26.07 *$ & $25.00 *$ & 25.54 \\
\hline & Mean (factor A) & $\mathbf{1 2 . 8 5}$ & 9.84 & 11.35 \\
\hline \multicolumn{5}{|c|}{$\mathrm{LSD}_{05}: \mathrm{A}-4.311, \mathrm{~B}-5.458, \mathrm{~A} \times \mathrm{B}-8.209$} \\
\hline \multicolumn{5}{|c|}{$\mathrm{K} \mathrm{kg} \mathrm{ha}^{-1}$} \\
\hline Organic I & aftermath of perennial grass & -8.72 & -5.24 & -6.98 \\
\hline Organic II & aftermath of perennial grass + farmyard manure $40 \mathrm{Mg} \mathrm{ha}^{-1}$ & $236.33 *$ & $229.69^{*}$ & $233.01 * *$ \\
\hline Sustainable I & farmyard manure $40 \mathrm{Mg} \mathrm{ha}^{-1}$ & $169.58 *$ & $158.66^{*}$ & $164.12 *$ \\
\hline \multirow[t]{3}{*}{ Sustainable II } & aftermath of perennial grass $+\mathrm{N}_{30} \mathrm{P}_{60} \mathrm{~K}_{60}$ & 45.05 & -10.48 & 17.29 \\
\hline & Mean (factor A) & 110.56 & 93.16 & 101.86 \\
\hline & $\mathrm{LSD}_{05}: \mathrm{A}-43.227, \mathrm{~B}-69.384, \mathrm{~A} \times \mathrm{B}$ & 1.425 & & \\
\hline
\end{tabular}

The application of perennial grasses aftermath as green manure alone in organic cropping system I resulted in a negative NPK balance in both humus levels. The application of both perennial grass aftermath and $40 \mathrm{Mg} \mathrm{ha}^{-1}$ of farmyard manure in organic cropping system II did not increase the yield significantly due to specific properties of clay loam - slow mineralization; the NP balance was highly positive and the potassium balance was excessive. Having only applied $40 \mathrm{Mg} \mathrm{ha}^{-1}$ of farmyard manure in the sustainable cropping system I, the $\mathrm{N}$ balance remained marginally positive in the soil of low humus content; a higher yield and a higher removal 
of $\mathrm{N}$ determined its highly negative balance in the soil of moderate humus content. In this system the phosphorus balance remained marginally positive and that of potassium - highly excessive in both soil humus content levels. The plant yield of the rotation was the highest in the soil of both humus levels in sustainable system II due to readily available nutrients from the mineral fertilizer, compared with other cropping systems. The amount of removed biogenic elements determined the negative $\mathrm{N}$ balance, the $\mathrm{P}$ balance was marginally positive, and only potassium balance was positive in low humus content soil and marginally negative in moderate humus content soil. At the beginning of rotation I, the richness of clay loam soils of low and moderate humus content in $\mathrm{P}$ differed significantly (Table 3 ).

Table 3. Changes of $\mathrm{P}_{2} \mathrm{O}_{5}$ amount in soil $\left(\mathrm{mg} \mathrm{kg}^{-1}\right)$

\begin{tabular}{|c|c|c|c|c|}
\hline \multirow{2}{*}{$\begin{array}{l}\text { Cropping system } \\
\text { (factor B) }\end{array}$} & \multirow{2}{*}{ Organic and mineral fertilizers } & \multicolumn{2}{|c|}{$\begin{array}{l}\text { Soil humus status } \\
\text { (factor } \mathrm{A})\end{array}$} & \multirow{2}{*}{$\begin{array}{c}\text { On average } \\
\text { (factor } \mathrm{B} \text { ) }\end{array}$} \\
\hline & & low & moderate & \\
\hline \multicolumn{5}{|c|}{ Beginning of rotation } \\
\hline Organic I & aftermath of perennial grass & 101.71 & 142.88 & 122.30 \\
\hline Organic II & aftermath of perennial grass + farmyard manure $40 \mathrm{Mg} \mathrm{ha}^{-1}$ & $68.46^{*}$ & $142.63 *$ & $105.55^{*}$ \\
\hline Sustainable I & farmyard manure $40 \mathrm{Mg} \mathrm{ha}^{-1}$ & $67.63 *$ & $124.58^{*}$ & $96.11^{*}$ \\
\hline \multirow[t]{3}{*}{ Sustainable II } & aftermath of perennial grass $+\mathrm{N}_{30} \mathrm{P}_{60} \mathrm{~K}_{60}$ & $124.46^{*}$ & 117.42 & 120.94 \\
\hline & On average (factor $\mathrm{A}$ ) & 90.57 & 131.88 & 111.23 \\
\hline & \multicolumn{3}{|c|}{$\mathrm{LSD}_{05}: \mathrm{A}-5.570, \mathrm{~B}-9.648, \mathrm{~A} \times \mathrm{B}-14.738$} & \\
\hline \multicolumn{5}{|c|}{ End of the first crop rotation, 2006-2009 } \\
\hline Organic I & aftermath of perennial grass & 85.56 & 115.44 & 100.50 \\
\hline Organic II & aftermath of perennial grass + farmyard manure $40 \mathrm{Mg} \mathrm{ha}^{-1}$ & $65.66^{*}$ & $141.34^{*}$ & 103.50 \\
\hline Sustainable I & farmyard manure $40 \mathrm{Mg} \mathrm{ha}^{-1}$ & $64.73 *$ & $141.46^{*}$ & 103.10 \\
\hline \multirow[t]{3}{*}{ Sustainable II } & aftermath of perennial grass $+\mathrm{N}_{30} \mathrm{P}_{60} \mathrm{~K}_{60}$ & $113.49 *$ & $135.54 * *$ & $124.52 *$ \\
\hline & On average (factor $\mathrm{A}$ ) & 82.36 & $133.45^{*}$ & 107.91 \\
\hline & \multicolumn{3}{|c|}{$\mathrm{LSD}_{05}: \mathrm{A}-4.67, \mathrm{~B}-8.089, \mathrm{~A} \times \mathrm{B}-12.356$} & \\
\hline \multicolumn{5}{|c|}{ End of the second crop rotation, 2010-2013 } \\
\hline Organic I & aftermath of perennial grass & 77.25 & $96.68 * *$ & 86.96 \\
\hline Organic II & aftermath of perennial grass + farmyard manure $40 \mathrm{Mg} \mathrm{ha}^{-1}$ & $62.25^{*}$ & $128.68^{* *}$ & $95.46^{*}$ \\
\hline Sustainable I & farmyard manure $40 \mathrm{Mg} \mathrm{ha}^{-1}$ & 71.18 & $122.83 * *$ & $97.00 *$ \\
\hline \multirow[t]{3}{*}{ Sustainable II } & aftermath of perennial grass $+\mathrm{N}_{30} \mathrm{P}_{60} \mathrm{~K}_{60}$ & $106.18^{* *}$ & $108.33^{* *}$ & $107.25 * *$ \\
\hline & On average (factor $\mathrm{A}$ ) & 79.21 & 114.13 & 96.69 \\
\hline & \multicolumn{3}{|c|}{$\mathrm{LSD}_{05}: \mathrm{A}-5.802, \mathrm{~B}-8.2056, \mathrm{~A} \times \mathrm{B}-11.604$} & \\
\hline
\end{tabular}

In the soil of low humus content, after the first crop rotation, a decrease in $\mathrm{P}_{2} \mathrm{O}_{5}$ amount was determined in the organic I and II and sustainable I cropping systems when using the perennial grass aftermath, farmyard manure or their combination for fertilization, which constituted respectively $15.9,4.1$ and $4.3 \%$ less compared with the amount at the beginning of the crop rotation. The farmyard manure, which had rather low $\mathrm{P}$ content $(0.89 \%)$ had no positive effect on the variations of $\mathrm{P}_{2} \mathrm{O}_{5}$ amount in the soil. At the end of the second crop rotation in all cropping systems, a decreasing tendency of the $\mathrm{P}_{2} \mathrm{O}_{5}$ amount was established compared with the initial data.

Low $\mathrm{P}$ content is a genetic property typical of heavy-textured soils. However, even under the effect of the means applied in the soil of low humus content, it remained within a group of low P content. At the beginning of the experiment, the soil had moderate $\mathrm{P}$ content (117.42-142.88 $\mathrm{mg} \mathrm{kg}^{-1}$ ) and moderate humus content. At the end of the first and the second crop rotations, $P$ content decreased significantly only in the cropping system I, in which only the perennial grass aftermath as green manure had been applied. The application of $40 \mathrm{Mg} \mathrm{ha}^{-1}$ of farmyard manure for fertilization resulted in a stable amount of $\mathrm{P}_{2} \mathrm{O}_{5}$ after the first rotation and having used it in combination with the perennial grass aftermath, a $13.5 \%$ increase was established. At the end of the second rotation, a decreasing mobile $\mathrm{P}$ tendency was established in all systems, which accounted for $13.5 \%$ of the total average compared with the initial data, excluding when only the perennial grass aftermath with a small amount of mineral fertilizer $\mathrm{P}_{60}$ had been applied.

There is a constant variation of different forms phosphorus in soil, therefore, a close connection between the balance of nutritious elements in cropping systems and the content of their mobile forms in soil is not always evident. The amount of the mobile forms of these elements in the soil only to some extent determines the efficiency of fertilizer applied to increase yield. The literature indicates that certain plants can assimilate the immobile forms of these elements via the contact of plant roots with soil, which determines the removal of yields and nutritious elements. The more mobile forms of the main nutritious elements in the soil, the lower efficiency of the incorporated phosphorus fertilizer (Blake et al., 2000; 2003).

Taken as an average of two humus content levels, the soil $\mathrm{P}$ content remained similar to the previous one after the first rotation, and after the second rotation, a signal decrease was established; it shows that the means applied were not sufficient to maintain stable $\mathrm{P}$ content of the soil.

A typical property of clay loam Cambisol is a high $\mathrm{K}$ content. The initial data on the mobile $\mathrm{K}$ amount at the beginning of the first rotation indicate that the difference between low and moderate humus content soils was lower compared to P. However, the total average of all cropping systems was significant and accounted for $9.0 \%$ (Table 4 ). 
Table 4. Changes of $\mathrm{K}_{2} \mathrm{O}$ amount in soil $\left(\mathrm{mg} \mathrm{kg}^{-1}\right)$

\begin{tabular}{|c|c|c|c|c|}
\hline \multirow{2}{*}{$\begin{array}{l}\text { Cropping system } \\
\text { (factor B) }\end{array}$} & \multirow[t]{2}{*}{ Organic and mineral fertilizers } & \multicolumn{2}{|c|}{$\begin{array}{l}\text { Soil humus status } \\
\text { (factor A) }\end{array}$} & \multirow{2}{*}{$\begin{array}{c}\text { On average } \\
\text { (factor B) }\end{array}$} \\
\hline & & low & moderate & \\
\hline \multicolumn{5}{|c|}{ Beginning of rotation } \\
\hline Organic I & aftermath of perennial grass & 218.92 & 220.88 & 219.90 \\
\hline Organic II & aftermath of perennial grass + farmyard manure $40 \mathrm{Mg} \mathrm{ha}^{-1}$ & $188.00 *$ & 224.21 & $206.11 *$ \\
\hline Sustainable I & farmyard manure $40 \mathrm{Mg} \mathrm{ha}^{-1}$ & $188.92 *$ & 223.88 & $206.40 *$ \\
\hline \multirow[t]{3}{*}{ Sustainable II } & aftermath of perennial grass $+\mathrm{N}_{30} \mathrm{P}_{60} \mathrm{~K}_{60}$ & $228.58 *$ & 229.67 & $229.13 *$ \\
\hline & On average (factor $\mathrm{A}$ ) & 206.10 & $224.66^{*}$ & 215.39 \\
\hline \multirow{2}{*}{\multicolumn{5}{|c|}{$\frac{\mathrm{LSD}_{05}: \mathrm{A}-1.974, \mathrm{~B}-3.419, \mathrm{~A} \times \mathrm{B}-5.223}{\text { End of the first crop rotation, } 2006-2009}$}} \\
\hline & & & & \\
\hline Organic I & aftermath of perennial grass & 197.96 & 211.50 & 204.73 \\
\hline Organic II & aftermath of perennial grass + farmyard manure $40 \mathrm{Mg} \mathrm{ha}^{-1}$ & 213.96 & $224.88^{*}$ & $219.42 *$ \\
\hline Sustainable I & farmyard manure $40 \mathrm{Mg} \mathrm{ha}^{-1}$ & 214.60 & $220.43 *$ & $217.52 *$ \\
\hline \multirow[t]{3}{*}{ Sustainable II } & aftermath of perennial grass $+\mathrm{N}_{30} \mathrm{P}_{60} \mathrm{~K}_{60}$ & 207.89 & $217.79 *$ & $212.84 *$ \\
\hline & On average (factor $\mathrm{A}$ ) & 208.60 & $218.65^{*}$ & 213.63 \\
\hline & \multicolumn{4}{|c|}{$\mathrm{LSD}_{05}: \mathrm{A}-2.842, \mathrm{~B}-4.923, \mathrm{~A} \times \mathrm{B}-7.520$} \\
\hline \multicolumn{5}{|c|}{ End of the second crop rotation, 2010-2013 } \\
\hline Organic I & aftermath of perennial grass & 198.83 & 209.18 & 204.00 \\
\hline Organic II & aftermath of perennial grass + farmyard manure $40 \mathrm{Mg} \mathrm{ha}^{-1}$ & 216.18 & $232.33 *$ & $224.25 *$ \\
\hline Sustainable I & farmyard manure $40 \mathrm{Mg} \mathrm{ha}^{-1}$ & $242.33 * *$ & $249.67 * *$ & $246.00 * *$ \\
\hline \multirow[t]{3}{*}{ Sustainable II } & aftermath of perennial grass $+\mathrm{N}_{30} \mathrm{P}_{60} \mathrm{~K}_{60}$ & 215.33 & 220.83 & 218.05 \\
\hline & On average (factor $\mathrm{A})$ & 218.16 & 228.00 & 223.08 \\
\hline & $\mathrm{LSD}_{05}: \mathrm{A}-12.483, \mathrm{~B}-17.653, \mathrm{~A} \times \mathrm{B}-2$ & 966 & & \\
\hline
\end{tabular}

At the end of the first crop rotation, the difference in the $\mathrm{K}_{2} \mathrm{O}$ amount between the humus content levels was decreasing. However, it remained significant and accounted for $4.8 \%$. Such results were determined by its marked decrease in the plots fertilized only with the perennial grass aftermath compared with the amount at the beginning of the crop rotation. Significant differences in $\mathrm{K}_{2} \mathrm{O}$ amount variations as the effect of the cropping systems were established only in the soil of moderate humus content after having used farmyard manure compared with the perennial grass aftermath; the interaction between both $(\mathrm{A} \times \mathrm{B})$ factors was insignificant. At the end of the second crop rotation, the $\mathrm{K}_{2} \mathrm{O}$ amount did not significantly differ, on average, between the different humus content levels in all cropping systems. The differences between the cropping systems at the end of this crop rotation were higher compared to those at the end of the first rotation. The highest amounts were established in the soils of low and moderate humus content having used farmyard manure and the perennial grass aftermath as fertilizer; the difference compared with the perennial grass aftermath as green manure accounted for $21.9 \%$ and $19.4 \%$, respectively.

Significantly higher $\mathrm{K}_{2} \mathrm{O}$ amounts were observed in the soils of low humus content of the cropping systems with only farmyard manure incorporation in the fourfield crop rotation: organic II $-13.8 \%$ and sustainable I $13.6 \%$, respectively compared with the initial ones. When using only the perennial grass aftermath as green manure in the organic I cropping system, negative changes of mobile $\mathrm{K}_{2} \mathrm{O}$ amounts in the soil were established $-9.6 \%$ lower than before the experiment. Similar negative $\mathrm{K}_{2} \mathrm{O}$ changes were also observed in the sustainable II cropping system, in which the perennial grass aftermath and mineral fertilizers $\mathrm{N}_{30} \mathrm{P}_{60} \mathrm{~K}_{60}$ were used.

Stable $\mathrm{K}_{2} \mathrm{O}$ in the soil of moderate humus content remained in the cropping systems that used farmyard manure or farmyard manure in combination with the perennial grass aftermath as green manure. After having used only the perennial grass aftermath in the organic I cropping system, the $\mathrm{K}_{2} \mathrm{O}$ amount decreased by $4.2 \%$ and in the sustainable II cropping system with the perennial grass aftermath and NPK, the amount of $\mathrm{K}_{2} \mathrm{O}$ decreased by $4.8 \%$ compared with the amount before the experiment.

On the basis of the investigations carried out on heavy-textured soils, it was established after the second crop rotation that both in the soils of low and moderate humus content of the cropping systems that used the perennial grass aftermath as green manure and the perennial grass aftermath in combination with minimum rates of mineral fertilizer, there were no positive changes in the amount of $\mathrm{K}_{2} \mathrm{O}$ compared with the amount before the experiment that could be determined by greater removal of nutrients together with the harvest. When the perennial grass aftermath as green manure in combination with farmyard manure had been applied in the cropping systems, the amount of $\mathrm{K}_{2} \mathrm{O}$ increased significantly by $11.5 \%$.

High $\mathrm{K}$ content is typical of the Cambisols of heavy texture; such soils release sufficient amounts of $\mathrm{K}$ compounds on a regular basis for the assimilation of plants and their supplies removed from the soil together with plant harvest have no great significance. The literature suggests that the role of farmyard manure is very important in maintaining the $\mathrm{K}$ regime in the soil, as solid manure has $0.57-0.62 \%$ of $\mathrm{K}$ on average; actually, its optimum incorporated amount of $40 \mathrm{Mg} \mathrm{ha}^{-1}$ can compensate for losses resulting from being removed from the soil through harvesting. If the soils with a genetic property of high $\mathrm{K}$ content are systematically fertilized with organic fertilizers in organic cropping systems, the $\mathrm{K}$ regime in soil can satisfy the needs of different crop rotation plants (Tripolskaja et al., 2013).

Farmyard manure, compared with green manure, increased the amounts of mobile $\mathrm{K}$ more effectively in the soils of moderate humus content compared with the soils of low humus content. At the end of the second crop rotation, a significantly higher $\mathrm{K}$ amount was established in the soil of low humus content only after having used 
farmyard manure in combination with the perennial grass aftermath compared with only the aftermath applied; in the soil of moderate humus content, a significant increase of $11.0 \%$ and $19.4 \%$ was established, both with only farmyard manure and with its combination with the perennial grass aftermath.

\section{Conclusions}

1. The NPK balance was negative in the organic I cropping system in both low and moderate levels of humus content when only aftermath of perennial grass had been used for green manure as fertilizer for winter wheat.

2. The NP balance was strongly positive and K was significantly excessive in organic II cropping system when the green manure had been used in combination with farmyard manure $40 \mathrm{Mg} \mathrm{ha}^{-1}$.

3. Available phosphorus content decreased and the potassium content increases significantly in the soil with low and moderate humus content where the winter wheat had been fertilized with aftermath of perennial grasses or $40 \mathrm{Mg} \mathrm{ha}^{-1}$ farmyard manure, or where a combination of both aftermath of perennial grasses and farmyard manure had been used.

4. When $40 \mathrm{Mg} \mathrm{ha}^{-1}$ of farmyard manure and $\mathrm{N}_{30}$ mineral fertilizers had been used in the sustainable I cropping system to promote straw mineralization, the nitrogen balance in the soil with the low humus content was slightly positive, in the soil with moderate humus content - strongly negative, due to a higher nitrogen removal with the wheat yield; in the soil of both humus levels phosphorus balance was slightly positive and that of potassium was significantly excessive.

5. In the soil of both low and moderate humus levels in the sustainable II cropping system which had received perennial grass aftermath as green manure and the perennial grass aftermath in combination with minimum rates of mineral fertilizer $\mathrm{N}_{30} \mathrm{P}_{60} \mathrm{~K}_{60}, \mathrm{~N}$ balance was negative, $\mathrm{P}$ - marginally positive. In the soil with low humus content $\mathrm{K}$ value was positive. In the soil with moderate humus content $\mathrm{K}$ value was marginally negative.

6. In the soil of both sustainable cropping systems, during two 4-course crop rotations the available phosphorus quantity demonstrated the trend towards decreasing. The available potassium quantity significantly increased in sustainable cropping systems $\mathrm{I}$, when farmyard manure had been used in the soil with both humus levels. In the sustainable cropping system II, when perennial grass aftermath for green manure and $\mathrm{N}_{30} \mathrm{P}_{60} \mathrm{~K}_{60}$ had been applied for winter wheat, the available potassium quantity demonstrated a marginal trend towards decreasing.

\section{Acknowledgments}

This work was part of the long-term research programme "Productivity and Sustainability of Agricultural and Forest Soils", implemented by the Lithuanian Research Centre for Agriculture and Forestry.

Received 24072015 Accepted 11012016

\section{References}

Arlauskienė A., Maikštennienė S., Šarūnaitė L., Kadžiulienė Ž., Deveikytė I., Žèkaitė V., Česnulevičienè R. 2011. Competitiveness and productivity of organically grown pea and spring cereal intercrops. Zemdirbyste-Agriculture, 4 (98): $339-348$
Benton Jones J. Jr. 2012. Plant nutrition and soil fertility manual ( $2^{\text {nd }}$ ed.) http://dx.doi.org/10.1201/b11577

Blake L., Mercik S., Koerschens M., Moskal S., Poulton P. R., Goulding K. W. T., Weigel A., Powlson D. S. 2000. Phosphorus content in soil, uptake by plants and balance in three European long-term field experiments. Nutrient Cycling Agroecosystems, 56: 263-275 http://dx.doi.org/10.1023/A:1009841603931

Blake L., Johnston A. E., Poulton P. R., Goulding K. W. T. 2003. Changes in soil phosphorus fractions following positive and negative phosphorus balances for long periods. Plant and Soil. 254: 245-261 http://dx.doi.org/10.1023/A:1025544817872

Cardelli R., Marchini F., Saviozzi A. 2012. Soil organic matter characteristics, biochemical activity and antioxidant capacity in Mediterranean land use systems. Soil and Tillage Research. 120: 8-14 http://dx.doi.org/10.1016/j.still.2012.01.005

Cerný V., Hruška L., Petr J. 2012. Yield formation in the main field crops

Chapin III F. S., Matson P. A., Vitousek P. M. 2012. Plant nutrient use. Principles of terrestrial ecosystem ecology. New York, USA, p. 229-258

Clough T. J., Condron L. M., Kammann C., Müller C. 2013. A review of biochar and soil nitrogen dvnamics. Agronomv. 3 (2): 275-293 http://dx.doi.org/10.3390/agronomy3020275

de-Bashan L. E., Hernandez J. P., Bashan Y. 2012. The potential contribution of plant growth-promoting bacteria to reduce environmental degradation - a comprehensive evaluation. Applied Soil Ecologv. 61: 171-189

http://dx.doi.org/10.1016/j.apsoil.2011.09.003

Diacono M., Montemurro F. 2010. Long-term effects of organic amendments on soil fertility. A review. Agronomy for Sustainable Develonment, 30 (2): 401-422 http://dx.doi.org/10.1051/agro/2009040

Edesi L., Järvan M., Noormets M., Lauringson E., Adamson A., Akk E. 2012. The importance of solid cattle manure application on soil microorganisms in organic and conventional cultivation. Acta Agriculturae Scandinavica, Section B: Soil and Plant Science. 62 (7): 583-594 http://dx.doi.org/10.1080/09064710.2012.678380

Eleiwa M. E., Hamed E. R., Shehata H. S. 2012. The role of biofertilizers and/or some micronutrients on wheat plant (Triticum aestivum L.) growth in newly reclaimed soil. Journal of Medicinal Plants Research, 6 (17): 3359-3369

Fageria N. K., Baligar V. C., Jones C. A. 2011. Growth and mineral nutrition of field crops ( $3^{\text {rd }}$ ed.). Boca Raton, USA

Feller C., Blanchart E., Bernoux M., Lal R., Manlay R. 2012. Soil fertility concepts over the past two centuries: the importance attributed to soil organic matter in developed and developing countries. Archives of Agronomy and Soil Science. 58 (suppl. 1): S3-S21

http://dx.doi.org/10.1080/03650340.2012.693598

Franzluebbers A. J. 2012. Soil organic carbon dynamics under conservation agricultural systems. Agrociencia, 16 (3): 162-174

Gliessman S. R. 2015. Agroecology: the ecology of sustainable food systems

Janušauskaitė D., Arlauskienė A., Maikštenienè S. 2013. Soil mineral nitrogen and microbial parameters as influenced by catch crops and straw management. Zemdirbvste-Agriculture, 100 (1): 9-18 http://dx.doi.org/10.13080/z-a.2013.100.002

Khan S., Afzal M., Iqbal S., Khan Q. M. 2013. Plantbacteria partnerships for the remediation of hydrocarbon contaminated soils. Chemosvhere. 90 (4): 1317-1332 http://dx.doi.org/10.1016/j.chemosphere.2012.09.045

Kumar S., Patra A. K., Singh D., Purakayastha T. J., Rosin K. G., Kumar M. 2013. Balanced fertilization along with farmyard manures enhances abundance of microbial groups and their resistance and resilience against heat stress in a semiarid Inceptisol. Communications Soil and Science Plant Analvsis. 44 (15): 2299-2313 http://dx.doi.org/10.1080/00103624.2013.803562

Ladha J. K., Reddy C. K., Padre A. T., van Kessel C. 2011. Role of nitrogen fertilization in sustaining organic matter in cultivated soils. Journal of Environmental Quality, 40 (6): $1756-1766$ http://dx.doi.org/10.2134/jeq2011.0064 
Luce M. S., Whalen J. K., Ziadi N., Zebarth B. J. 2011. Nitrogen dynamics and indices to predict soil nitrogen supply in humid temperate soils. Advances in Agronomy, 112: 55-102 http://dx.doi.org/10.1016/B978-0-12-385538-1.00002-0

Masilionytė L., Maikštènienè S. 2010. The influence of various organic fertilizers and catch crops on the balance of biogenic elements in the agrosystems. ZemdirbysteAgriculture, 97 (2): 41-52

Oerke E. C., Dehne H. W., Schönbeck F., Weber A. 2012. Crop production and crop protection: estimated losses in major food and cash crops

Osman K. T. 2013. Plant nutrients and soil fertility management. Soils. The Netherlands. p. 129-159 http://dx.doi.org/10.1007/978-94-007-5663-2 10

Roychowdhury R., Banerjee U., Sotkova S., Tah J. 2013. Organic farming for crop improvement and sustainable agriculture in the era of climate change. Journal of Biological Sciences. 13 (2): 55-70 http://dx.doi.org/10.3844/ojbsci.2013.50.65

Sedlář O., Balík J., Kozlovský O., Peklová L., Kubešová K. 2011. Impact of nitrogen fertilizer injection on grain yield and yield formation of spring barley (Hordeum vulgare L.). Plant, Soil and Environment, 57: 547-552

Spiess E. 2011. Nitrogen, phosphorus and potassium balances and cycles of Swiss agriculture from 1975 to 2008 . Nutrient
Cycling Agroecosystems. 91 (3): 351-365

http://dx.doi.org/10.1007/s10705-011-9466-9

Standing D., Killham K. 2012. Sustainable management of soil and plant health by optimising soil biological function. Soil conditions and plant growth, p. 366-389

Tan H., Barret M., Mooij M. J., Rice O., Morrissey J. P., Dobson A., Griffiths B., O'Gara F. 2013. Long-term phosphorus fertilisation increased the diversity of the total bacterial community and the phoD phosphorus mineraliser group in nasture soils. Biology and Fertility of Soils, 49 (6): 661-672 http://dx.doi.org/10.1007/s00374-012-0755-5

Tarakanovas P., Raudonius S. 2003. Agronominių tyrimų duomenų statistine analize taikant kompiuterines programas $A N O V A$, STAT, SPLIT-PLOT iš paketo SELEKCIJA ir IRRISTAT. Lithuanian University of Agriculture, 58 p. (in Lithuanian)

Tiziano G., Pimentel D., Paoletti M. G. 2011. Environmental impact of different agricultural management practices: conventional vs. organic agriculture. Critical Reviews in Plant Sciences, 30 (1-2): 95-124

Tripolskaja L. 2005. Organic fertilisers and their effect on the environment. Lithuanian Institute of Agriculture, $214 \mathrm{p}$. (in Lithuanian)

Tripolskaja L., Booth C. A., Fullen M. A. 2013. A lysimeter study of organic carbon leaching from green manure and straw into a sandy loam Haplic Luvisol. Zemdirbyste-Agriculture, 100 (1): 3-8 http://dx.doi.org/10.13080/z-a.2013.100.001

ISSN 1392-3196 / e-ISSN 2335-8947

Zemdirbyste-Agriculture, vol. 103, No. 1 (2016), p. 3-10

DOI 10.13080/z-a.2016.103.001

\section{Pagrindinių mitybos elementų pokyčiai dirvožemyje taikant alternatyvias žemdirbystės sistemas}

\section{Masilionytè, S. Maikštėnienè}

Lietuvos agrarinių ir miškų mokslų centro Joniškèlio bandymų stotis

\section{Santrauka}

Tyrimai atlikti Lietuvos agrarinių ir miškų mokslų centro Joniškèlio bandymų stotyje 2006-2013 m. mažo $(<2,0)$ ir vidutinio $(>2,1)$ humusingumo sunkaus priemolio giliau glëjiškame rudžemyje (RDg4-k2), kuriam būdingas mažas fosforingumas ir didelis kalingumas. Sejjomaina: miežiai (Hordeum vulgare L.), veislè 'Ula' + įsèlis $\rightarrow$ daugiametès žolès (raudonieji dobilai (Trifolium pratense L.), veislè 'Vyliai') $\rightarrow$ žieminiai kviečiai (Triticum aestivum L.), veislè 'Ada' $\rightarrow$ žirniai (Pisum sativum L.), veislè 'Pinochio'. Tyrimų tikslas - nustatyti biogeninių elementų pokyčius dirvožemyje ekologinėse žemdirbystès sistemose žieminių kviečių tręšimui naudojant mèšlą, raudonujų dobilų atolą žaliajai trąšai ar jų abiejų derinius, o tausojamosiose - mitybos elementus papildant mineralinemis trąšomis.

Abiejų humusingumo lygių dirvožemyje ekologinèje žemdirbystės sistemoje, kurioje žieminiai kviečiai tręšti vien tik daugiamečiu žolių atolu, NPK balansas buvo neigiamas. Ekologinèje žemdirbystès sistemoje, kurioje trąšai naudotas daugiamečių žolių atolas kartu su $40 \mathrm{Mg} \mathrm{ha}^{-1}$ méšlo, NP balansas buvo stipriai teigiamas, $\mathrm{K}$ esmingai perteklinis. Taikant šias žemdirbystès sistemas po dviejų 4-ių laukų rotacijų dirvožemyje nustatytas žymus judriojo fosforo kiekio sumažejimas. Judriojo kalio kiekio neigiami pokyčiai nustatyti tik ekologinejje žemdirbystės sistemoje, kurioje kaip trąša naudotas daugiamečių žolių atolas; tręšimas mèšlu turèjo tendenciją didinti kalio kiekį. Tausojamojoje žemdirbystès sistemoje, kurioje žieminiai kviečiai tręšti $40 \mathrm{Mg} \mathrm{ha}^{-1}{\text { méšlo ir } \mathrm{N}_{30}}$ mineralinėmis trąšomis šiaudų mineralizacijai skatinti, $\mathrm{N}$ balansas mažo humusingumo dirvožemyje buvo silpnai teigiamas, o vidutinio dèl didesnio išnešimo su derliumi - stipriai neigiamas; esant abiem humusingumo lygiams fosforo balansas buvo nežymiai teigiamas, kalio gerokai perteklinis. Tausojamojoje žemdirbystės sistemoje, kurioje žieminiai kviečiai tręšti daugiamečių žolių atolu kartu su mineralinėmis $\mathrm{N}_{30} \mathrm{P}_{60} \mathrm{~K}_{60}$ trąšomis, esant abiem humusingumo lygiams $\mathrm{N}$ balansas buvo neigiamas, $\mathrm{P}$ - nežymiai teigiamas, $\mathrm{K}$ mažo humusingumo dirvožemyje teigiamas, vidutinio - nežymiai neigiamas.

Po dviejų 4-ių laukų sẻjomainos rotacijų, tausojamojoje žemdirbystès sistemoje žieminius kviečius tręšiant daugiamečiu žoliu atolu ir mineralinėmis $\mathrm{N}_{30} \mathrm{P}_{60} \mathrm{~K}_{60}$ trąšomis, mažo ir vidutinio humusingumo dirvožemyje nustatyta judriųjų fosforo bei kalio kiekių mažéjimo tendencija.

Reikšminiai žodžiai: ekologine ir tausojamoji žemdirbystès sistemos, judrieji $\mathrm{P}_{2} \mathrm{O}_{5}$ ir $\mathrm{K}_{2} \mathrm{O}$, maisto medžiagu balansas, mèšlas ir žalioji trą̌sa.

Please use the following format when citing the article:

Masilionyte L., Maikšteniene S. 2016. The effect of alternative cropping systems on the changes of the main nutritional elements in the soil. Zemdirbyste-Agriculture, 103 (1): 3-10 DOI 10.13080/z-a.2016.103.001 